Ширяева Татьяна Ивановна

кандидат юридических наук, доцент, доцент кафедры уголовного процесса Волгоградской академии МВД России

\section{ЗАЩИТА ПРАВ И ЗАКОННЫХ ИНТЕРЕСОВ ЛИЦ, ПОТЕРПЕВШИХ ОТ ПРЕСТУПЛЕНИЙ, И ЕЕ СОДЕРЖАНИЕ ПРИ ПРОИЗВОДСТВЕ ПО УГОЛОВНЫМ ДЕЛАМ}

\begin{abstract}
Аннотация:
Уголовное судопроизводство имеет своим назначением защиту лиц и организаций, потерпевших от преступлений. В свете постоянного реформирования уголовно-процессуального законодательства изменению подвергается правовой статус участников уголовного судопроизводства, в том числе и потерпевиих. В статье исследованы вопросы обеспечения прав и законных интересов лии, потерпевшux om производства по уголовным делам; рассмотрены выделяемые в науке и применяемые в практической деятельности способы защиты прав и законных интересов лиц и организаций, потерпевших от преступлений; выявлены проблемы, связанные с их реализацией. В результате проведенного исследования выработаны рекомендации по совершенствованию деятельности по защите прав и законных интересов лии, потерпевших от преступлений, на протяжении всего уголовного судопроизводства, в том числе и на досудебных стадиях.
\end{abstract}

Ключевые слова:

уголовное судопроизводство, обеспечение прав, законные интересы, участники, правовой статус, потерпевший, защита участников, право на защиту.
Shiryaeva Tatyana Ivanovna

PhD in Law, Associate Professor, Criminal Procedure Department, Volgograd Academy of the Ministry of Internal Affairs of Russia

\section{PROTECTION OF RIGHTS AND LEGITIMATE INTERESTS OF INDIVIDUALS AFFECTED BY CRIME IN CRIMINAL PROCEEDINGS}

Keywords: criminal proceedings, ensuring the rights, legitimate interests, parties, legal status, victim, protection of parties, right to defence.

Действующее в настоящее время уголовно-процессуальное законодательство предусматривает в качестве одного из проявлений назначения уголовного судопроизводства защиту прав и законных интересов лиц и организаций, потерпевших от преступлений (п. 1 ч. 1 ст. 6 Уголовнопроцессуального кодекса Российской Федерации (далее - УПК)). Исходя из того, что рассматриваемое положение помещено законодателем в ст. 6 УПК РФ, которая находится в главе 2 «Принципы уголовного судопроизводства», оно действует на всем протяжении уголовного судопроизводства. В связи с этим максимально полное и всестороннее уяснение его смысла является необходимым условием успешности уголовного судопроизводства как необходимой составляющей функционирования всей системы отечественных общественных отношений в условиях построения в России интегрированного в международное содружество правового государства.

По официальным данным Главного информационно-аналитического центра Министерства внутренних дел Российской Федерации, за период с января по октябрь 2017 г. на территории Российской Федерации зарегистрировано 1755837 преступлений, при этом из числа преступлений, дела и материалы о которых находились в производстве, в отчетном периоде раскрыто 944815 преступлений, что на 6,8 \% меньше, чем за аналогичный период прошлого года; нераскрытыми же из числа преступлений, дела и материалы о которых находились в производстве, остались 679415 преступлений [1]. Несмотря на положительную динамику, следует учитывать, что данный показатель отражает ситуацию только по уголовным делам, направленным для дальнейшего рассмотрения в суд, либо по уголовным делам, производство по которым прекращено в стадии предварительного расследования, что может с определенной долей вероятности гарантировать дальнейшее обеспечение прав и законных интересов лиц и организаций, потерпевших от преступлений, посредством применения не только средств уголовного судопроизводства, но и иных способов, в частности, в рамках гражданского судопроизводства. В остальных же случаях 
для реализации такой возможности лицо, потерпевшее от преступления, вынуждено ожидать окончания производства по уголовному делу длительное время, что приобретает особое значение в условиях действия принципа разумного срока уголовного судопроизводства и при условии неустановления лица, совершившего преступление. Изложенное свидетельствует о необходимости уделять особое внимание вопросам деятельности государственных органов, уполномоченных осуществлять производство по уголовным делам, в части защиты прав и законных интересов лиц и организаций, потерпевших от преступлений.

Идея о восприятии человека и гражданина как высшей ценности государства, в том числе в части защиты и обеспечения присущих им прав и свобод, является концептуальной, гарантированной не только на государственном, но и на международном уровне. Однако в отличие от УПК РФ, правовые акты, в том числе и международные, имеющие приоритетное значение, провозглашают в качестве основного ориентира государственной деятельности в уголовно-процессуальной сфрере общественных отношений осуществление не только защиты прав и законных интересов потерпевших от преступлений лиц и организаций, но и их соблюдения, обеспечения, охраны, а также возмещения им вреда, причиненного в результате совершения преступления. В связи с этим как в досудебном, так и в судебном производстве по уголовному делу как составляющих уголовное судопроизводство в целом (п. 56 ст. 5 УПК РФ) вся деятельность должна быть направлена на реализацию данных установлений.

Следует отметить, что понятие «защита» упоминается в уголовно-процессуальном законе, по нашим подсчетам, более пятидесяти раз, ввиду чего его значение неоднократно подвергалось анализу на страницах юридических изданий [2]. Из них применительно к установлению правового статуса потерпевшего данный термин используется менее десяти раз, в остальных случаях его употребление связано либо с осуществлением соответствующей функции в деятельности стороны защиты в рамках состязательного построения уголовного судопроизводства [3], либо с осуществлением деятельности по обеспечению безопасности лиц, участвующих в производстве по уголовному делу [4]. Подобное решение законодателя не может быть признано оптимальным ни для науки, ни для практики, поскольку ведет к разночтению одних и тех же терминов в зависимости от контекста.

В соответствии со словарем С.И. Ожегова, «защитить» значит «охраняя, оградить от посягательств, от враждебных действий, от опасности, обезопасить» [5, с. 228]. Исходя из этого, в рамках уголовного процесса целью деятельности должно выступать не только недопущение новых фактов нарушения в процессе осуществления такого производства прав и законных интересов потерпевших, как их защита, но и восстановление охраняемых законом прав, которые уже нарушены преступлением. То есть в ее содержание необходимо включать комплекс действий по соблюдению, обеспечению, защите и восстановлению прав и законных интересов таких лиц.

Положительное влияние на правоприменительную практику в части защиты прав потерпевшего оказало обращение законодателя к вопросам обеспечения прав потерпевших при производстве по уголовным делам, выразившееся в принятии 28.12.2013 Федерального закона № 432-Ф3 «О внесении изменений в отдельные законодательные акты Российской Федерации в целях совершенствования прав потерпевших в уголовном судопроизводстве». В результате внесения данным законом изменений в уголовно-процессуальное законодательство значительному реформированию в сторону усиления подверглась система уголовно-процессуальных гарантий реализации конституционных положений о государственной защите лиц, потерпевших от преступлений и злоупотреблений властью, а также прав на доступ к правосудию и компенсацию причиненного ущерба. Хочется верить, что принятие данного закона, как и в зарубежных странах, ознаменовало начало процесса приведения внутрироссийского законодательства в соответствие с требованиями международных правовых актов в части улучшения положения потерпевших [6, р. 421-422]. Следует отметить, что названный нормативный правовой акт явился первым, на законодательном уровне усовершенствовавшим правовое положение потерпевших от преступлений в уголовном судопроизводстве. Однако не все привнесенные им в УПК РФ нововведения имеют положительный характер.

В результате внесения изменений в ч. 1 ст. 42 УПК РФ существенное изменение претерпела законодательная регламентация определения момента придания лицу процессуального статуса потерпевшего по уголовному делу. В отличие от ранее действовавшей редакции данная норма закрепила требование о незамедлительности по отношению к моменту возбуждения уголовного дела признания лица, которому преступлением причинен предусмотренный законом вред, потерпевшим. При этом законодатель учел и возможное отсутствие у органов, принявших решение о возбуждении уголовного дела, информации о лице, понесшем такой вред. В данном случае лицо получило возможность быть признанным потерпевшим немедленно после его установления. Такое решение законодателя позволило обеспечить возможность реализации права на доступ потерпевшего к механизму уголовного судопроизводства на максимально раннем 
этапе производства по уголовному делу [7, с. 9], что заслуживает положительной оценки с точки зрения обеспечения конституционных прав потерпевшего в уголовном судопроизводстве.

При этом все так же недостаточно ясным осталось использованное законодателем понятие «незамедлительно». В соответствии со словарем С.И. Ожегова, данный термин означает «немедленный, без задержек» [8, с. 995]. Представляется, что с учетом правил определения процессуальных сроков в уголовном судопроизводстве с целью обеспечения наиболее скорого вовлечения потерпевшего лица в уголовное судопроизводство постановление о признании потерпевшим должно быть вынесено в максимально короткий срок с момента либо возбуждения уголовного дела, либо установления лица, которому преступлением причинен вред.

Реализация в уголовном судопроизводстве прав и законных интересов лиц и организаций, потерпевших от преступлений, может быть рассмотрена как многоаспектный процесс, включающий в себя деятельность различных лиц: 1) самих лиц, потерпевших от преступлений, и признанных таковыми в процессе производства по уголовному делу; 2) государственных органов и должностных лиц, осуществляющих производство по уголовному делу; 3) иных участников уголовного судопроизводства. При этом деятельность лиц и организаций, признанных потерпевшими по уголовному делу, выражается в реализации ими как процессуального, так и общеконституционного статусов потерпевшего от преступления; деятельность государственных органов проявляется как многоаспектный процесс, включающий в себя следующие составляющие: 1) непосредственное соблюдение в своей деятельности правового статуса потерпевшего; 2) обеспечение соблюдения в деятельности иных лиц указанного статуса; 3) создание условий для самостоятельной реализации потерпевшим своего правового статуса в процессе участия в уголовном судопроизводстве.

При этом в рамках реализации охранительной составляющей в качестве общей черты, характеризующей деятельность любых субъектов в целях обеспечения полноценного воплощения в жизнь прав и законных интересов лиц и организаций, признанных потерпевшими, в процессе производства по уголовному делу представляется возможным обозначить направленность на исключение каких-либо препятствий к этому. Восстановительная же компонента рассматриваемой деятельности выражается не в исключении негативного воздействия на процесс осуществления правового статуса потерпевшего в процессе производства по уголовному делу, а в приведении в результате уголовного судопроизводства правового положения лица, потерпевшего от преступления, в первоначальный, существовавший до противоправного воздействия вид. Реализация обозначенных компонентов на протяжении всего уголовного судопроизводства в их совокупности, как видится, позволит достичь в полной мере назначения уголовного судопроизводства в части защиты прав и законных интересов лиц, потерпевших от преступлений.

В заключение представляется возможным сделать следующие выводы: во-первых, понятие потерпевшего, употребляемое в УПК РФ, используется исключительно для обозначения правового статуса лица, на обеспечение прав и законных интересов которого, в том числе нарушенных преступлением, направлено уголовное судопроизводство; во-вторых, определенная в качестве назначения уголовного судопроизводства защита прав и законных интересов лиц, потерпевших от преступлений, должна рассматриваться правоприменителями как многоаспектное понятие, включающее в себя как охранительный, так и восстановительный компоненты; в-третьих, обязательность соблюдения и обеспечения прав и законных интересов лиц, потерпевших от преступлений, хоть и в различной степени, должна реализовываться всеми участниками уголовного судопроизводства, при этом деятельности ведущих производство по уголовному делу государственных органов и должностных лиц присущ, как видится, организующий характер. Реализация выработанных положений позволит обеспечить надлежащий уровень обеспечения прав и законных интересов лиц и организаций, потерпевших от преступлений, в том числе и на досудебных стадиях уголовного судопроизводства.

\section{Ссылки:}

1. Состояние преступности в России за январь - октябрь 2017 года [Электронный ресурс] // https://мвд.pф/folder/101762/item/11715403/ (дата обращения: 30.11.2017).

2. Насонова И.А. Уголовно-процессуальное понятие защиты // Пробелы в российском законодательстве. 2009. № 3. C. $166-168$.

3. Печников Г.А., Блинков А.П. О гарантиях прав личности в свете приоритета «формы» над «истиной» в состязательном УПК РФ // Бизнес в законе. 2009. № 3. С. 130-132.

4. Чмырёв С.Н. Правовое положение деятельности милиции по государственной защите потерпевшего как участника уголовного судопроизводства // Там же. С. 81-83.

5. Ожегов С.И. Словарь русского языка : 70000 слов. 23-е изд., испр. / под ред. Н.Ю. Шведовой. М., 1991.

6. Waller I. Victima vs Regina vs Malefactor: Justice for the Next 100 Years // Criminal Law in Action: An Overview of Current Issues in Western Societies / ed. by Ch. Haffmans, [etc.]. Arnhem, 1987. P. 419-438.

7. Якуб М.Л. Процессуальная форма в советском уголовном судопроизводстве. М., 1981.

8. Ожегов С.И. Указ. соч. 


\section{References:}

Chmyrev, SN 2009, 'Legal status of the militia on state protection of the victim as a participant of criminal proceedings', Biznes v zakone, No. 3, pp. 81-83, (in Russian).

Nasonova, IA 2009, 'The criminal procedural concept of protection', Probely v rossiyskom zakonodatel'stve, No. 3, pp. 166168, (in Russian). sian).

Ozhegov, SI \& Shvedova, NYu (ed.) 1991, Dictionary of the Russian language: 70,000 words, 23rd ed., Moscow, (in Rus-

Pechnikov, GA \& Blinkov, AP 2009, 'Guarantees of individual rights resulting from the priority of "form" over "truth" in the adversarial Criminal Code of the Russian Federation', Biznes v zakone, No. 3, pp. 130-132, (in Russian).

Waller, I \& Haffmans, Ch (et al.) (eds.) 1987, 'Victima vs Regina vs Malefactor: Justice for the Next 100 Years', Criminal Law in Action: An Overview of Current Issues in Western Societies, Arnhem, pp. 419-438.

Yakub, ML 1981, Procedural form in the Soviet criminal proceedings, Moscow, (in Russian). 